\section{Online 3D Oil Palm Plantation Management BASED ON GAME ENGINE: A CONCEPTUAL IDEA}

\author{
Ruzinoor Che Mata*, Abdul Nasir Zulkiflia, Norani Nordin', Shahrul \\ Azmi Mohd Yusofc
}

aschool of Multimedia Technology and Communication, Universiti Utara Malaysia, Malaysia

bSchool of Technology Management and Logistic, Universiti Utara Malaysia, Malaysia

cSchool of Computing, Universiti Utara Malaysia, Malaysia
Article history

Received

15 June 2015

Received in revised form

1 October 2015

Accepted

13 October 2015

${ }^{*}$ Corresponding author ruzinoor@gmail.com

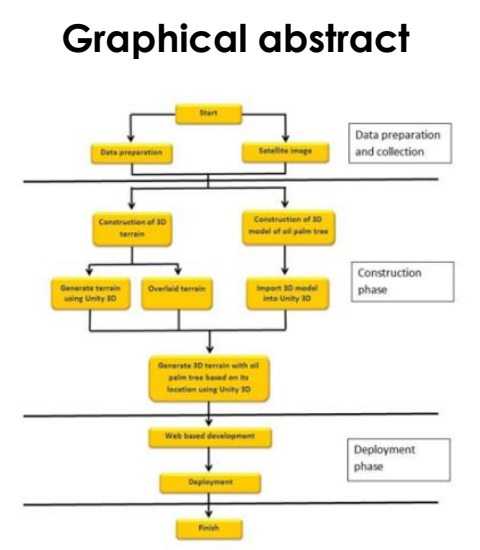

\begin{abstract}
The main commodity export of Malaysia is still oil palm which is known as the backbone of Malaysian agriculture. Various problems and techniques on managing oil palm plantation has been introduces by many researchers and found that monitoring the status of oil palm plantation through online facility is very important. This could be achieved by using game engine technology. This paper discussed the conceptual idea of developing an online 3D oil palm management system based on game engine technology. The game engine can be utilized to simulate the management of an oil palm plantation, as using 3D will allow a lot more information to be conveyed. Game engines allow so much customization as able to construct an online 3D oil palm plantation. This idea would be beneficial to everyone especially future developers who might expand this idea.
\end{abstract}

Keywords: Oil palm, Online, 3D, Game Engine, Visualization

\begin{abstract}
Abstrak
Eksport utama komoditi di Malaysia masih lagi industri kelapa sawit yang dikenali sebagai tulang belakang pertanian Malaysia. Pelbagai masalah dan teknik pengurusan ladang kelapa sawit telah diperkenalkan oleh ramai penyelidik dan mereka mendapati pemantauan status ladang kelapa sawit melalui kemudahan dalam talian adalah sangat penting. Perkara ini boleh dicapai dengan menggunakan teknologi enjin permainan. Tujuan utama kajian ini adalah untuk membincangkan tentang idea konsep untuk membangunkan kemudahan dalam talian sistem pengurusan kelapa sawit 3D berasaskan teknologi enjin permainan. Enjin permainan boleh digunakan untuk membuat visualisasi pengurusan ladang kelapa sawit, dengan menggunakan 3D akan membolehkan lebih banyak maklumat yang akan disampaikan. Enjin permainan membenarkan terlalu banyak penyesuaian yang boleh dilakukan yang membolehkan pembinaan ladang kepala sawit 3D secara atas talian. Idea ini memberi faedah kepada sesiapa sahaja terutama sekali pembangun sistem pada masa akan datang yang mungkin akan mengembangkan lagi idea ini.
\end{abstract}

Kata kunci: Kelapa sawit, Dalam talian, 3D, Enjin Permainan, Visualisasi

(C) 2016 Penerbit UTM Press. All rights reserved

\subsection{INTRODUCTION}

In recent years a range of new 3D objects and 3D creation software became available for public use.
Such as, Autodesk 3D studio max, google Sketchup and blender. Each of these software's able to create 3D object and capable of high quality animation, games, education, architectures and Geographical 
Information System (GIS) application. Three dimensional (3D) objects always able to show more information compare to two dimensional (2D) objects. As a 3D object can display information from $X, Y$ and $Z$ angle compare to 2D object which only shows $X$ and $Y$. Thus allowing the 3D dimensional object to be able to show the volume of the objects [1]. In GIS, the 3D object is used widely in displaying terrain in the 3D model. This is also true for the game engine as game engine emulate the environment, thus using 3D model inside the game engine with GIS data would allow more data manipulation to be done. This kind of technology could be utilized for managing of oil palm plantation.

For example, MIMOS and Felda Agricultural Services San Bhd (FAS) has introduced "Ladang Digital Kelapa Sawit" where most of the latest digital technology were utilized such as Micro Electro Mechanical System Sensor (MEMS), semantic technology, wireless technology, and grid computing [2]. Other than this, Adaem [3] has introduced the idea on how to develop Ladang Digital which focusing on Ladang Kepala Sawit Digital. Until now, there are no proper Ladang Kepala Sawit Digital being published in the market. This paper will discuss the conceptual idea of developing online 3D oil palm management system based on game engine technology.

\subsection{LITERATURE REVIEW}

The conceptual idea of this project is actually related to the game engine based technology and also 3D visualization for managing oil palm plantation. Game engine can be defined as a collection of tools that help the creation of games to be much faster [4] and it utilize the latest computer graphic technology and able to be applied for multiplayer mode [5] which also that game engine supports online that is connected through the internet. The Game engine can be seen in several type of infrastructure, one of the infrastructures named as modular [6]. The infrastructure can be seen as layers which started from virtual coding into visualizing the content into a playable game. These layers can be seen as inputs, physics, renderer, core, scripting and networking [7].

3D visualization usually referred as a view that utilized three axis to create a sense of depth [8], 3D have three major part to look at that is length, width and height or $X, Y$ and $Z$, study conducted utilize the axis to analyze LADAR data in real time [9]. 3D is also used mostly in Virtual Reality (VR) environments, VR allows immersive [10] as in Second Life [11] and with the current trend of Head Mounted Device (HMD) such as oculus rift [12] and a few HMD device that is in development stages like True Player Gear Totem or Vrvana [13] and Gameface [14] that will allow a better 3D view. These HMD devices are created to allow support to 3D game created using game engine as game engine is a software that help in the development of current game [15], Uncharted which was developed using the Naughty Dog Game Engine
[16], titled such as Crysis, which was developed using CryENGINE [17] and games created using Unity 3D such as the golf club created by $\mathrm{Hb}$ Studios [18] . In spite of games, the game engine has also been used to develop simulations for training purposes such as Virtual Battlespace Systems 2 (VBS2) and Virtual Heroes is among the simulation created using the game engine [19] . Incorporating GIS data inside the game allow a much realistic simulation. This kind of simulation also can be used as a management tool for other purposes. Ruzinoor et al. [20] reviewed the game engine capability of handling GIS data. This is also discussed by Sa et al. [21] using Unity 3D to simulate a VR environment using GIS data inside the game engine.

In recent years, oil palm management became a much discussed topic among researchers. Tan et al. [22] provided guidance on Best Management Practices (BMP) to optimize oil palm cultivation based on current knowledge and field experience. Some of the practices are; for efficient water management, fertilizer and nutrient management, integrated pest, and disease management, effective weed management, management on leaning and fallen palms, replanting practices and nursery management. In other hand, the research conducted by Bergert [23] explained the farming system, cropping system and the land tenure system which is methods used in the oil palm management that focused on the land itself. Donough, Witt and Fairhurst [24] has done a report on yield intensification in oil palm plantations. For oil palm plantations, inputs are usually both affordable and available and estates obtain seed with high yield potential from certified seed producers. Thus, better agronomic management and estate organization and planning is the key to improved yields. For replanting oil palm, Tan et al. [23] describes the zero burning technique which is a method of land clearing whereby the existing plantation is felled, shredded, stacked and left in-situ to decompose naturally. There are few basic steps in zero burning technique which included plans for replanting, removal of diseased palms, pre-lining, planning and implementation of new roads and drains, felling and shredding, stacking, lining, holding and planting of oil palm seedlings, pulverization and post-planting management. Sharma [25] also researched on zero burning techniques, planting materials, nursery management and stated the importance of soil health maintenance and prevention of erosion. His research also focused on the recycling of mill by-products by land application in plantations for the promotion of better crop growth and production. Implementation of best management practices (BMPs), including soil phosphorus (P) recapitalization, resulted in a rapid increase in palm nutrient status and yield in oil palm rehabilitation [26]. 


\subsection{PROPOSED METHODOLOGY FOR DEVELOPING OF ONLINE 3D OIL PALM PLANTATION MANAGEMENT SYSTEM BASED ON GAME ENGINE}

The methodology of developing an online 3D oil palm management system can be divided into three stages. Figure 1 show the methodology based on game engine. First stage will gather information by taking opinion of the experts by interview. An interview protocol should be set first. Experts will be chosen from online 3D visualization experts of academia, practitioners and private company representatives. On the other hand, experts in oil palm plantation management will also be interviewed. The results of the analysis could be performed using qualitative data analysis. On the second stage a prototype will be developed of online $3 \mathrm{D}$ oil palm plantation management system based on the results from Stage One. The final stage involved survey among oil palm managers to analyze and validate the prototype to be developed. Questionnaires containing dimensions related to the prototype will be asked to the selected oil palm plantation.

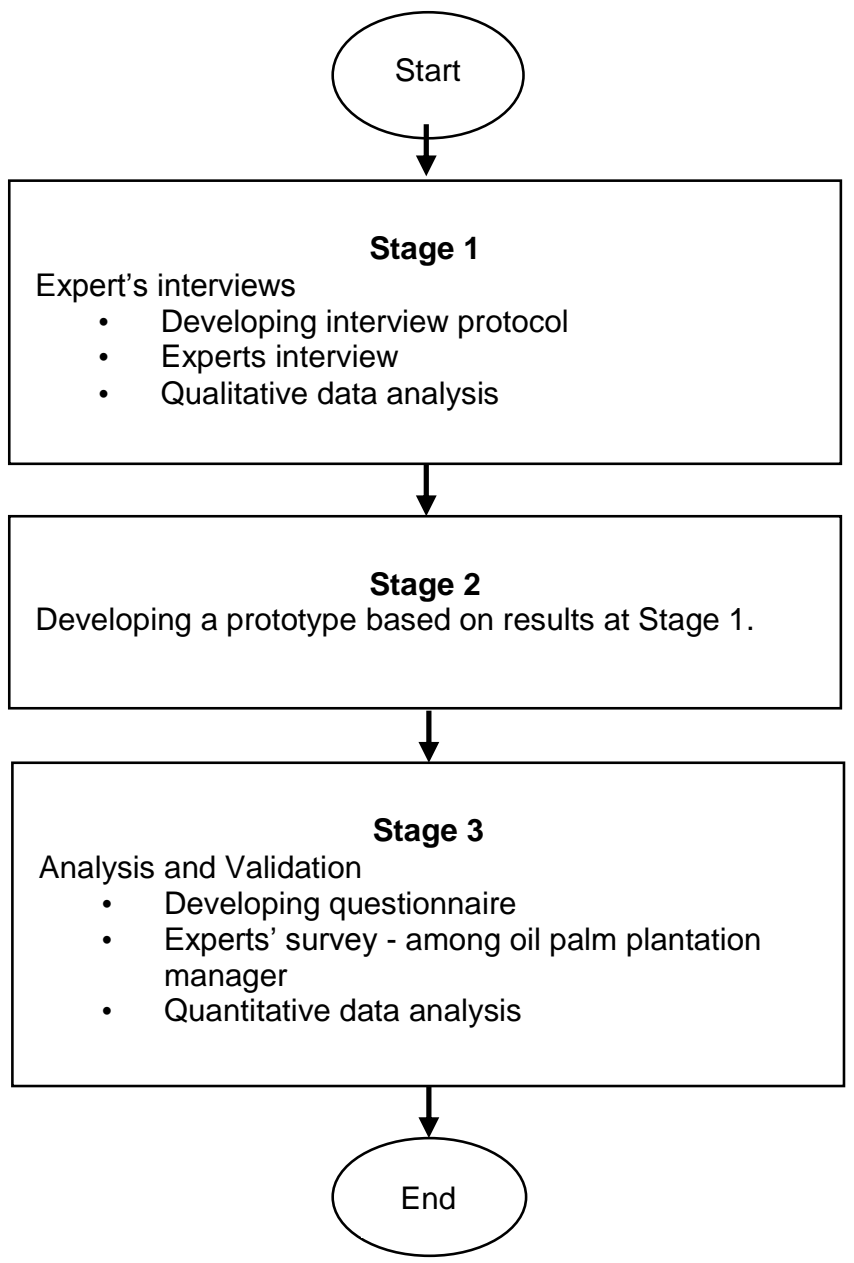

Figure 1 Proposed methodology for developing of online 3D oil palm management system based on game engine technology

\subsection{RESULTS AND DISCUSSION}

In order to fulfill the second stage for developing online 3D oil palm management system based on game engine, the proposed development flow has been introduced as shown in Figure 2. It shows the steps that could be undertaken for developing the system. It is divided into 3 major phases which are the core for the development process. The phases are data preparation and collection, constructions phase and deployment phase.

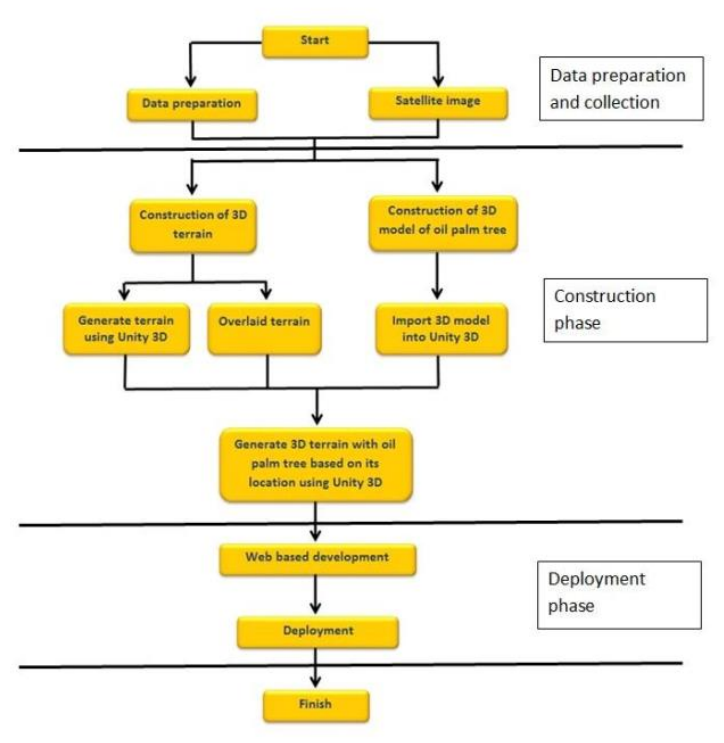

Figure 2 The development flow diagram of the oil palm management system

\subsection{Data Preparation and Collection}

In this phase data and information regarding terrains and oil palm is collected and analysed if necessary. The purpose of this process is to make sure that the data collected meets the requirement needed. In this phase, also the information regarding the characteristic, such as, leaf colour and trunk size of oil palm tree is collected.

\subsection{Construction Phase}

During the construction phase, the data collected could be used and applied, as the data on terrains and oil palm tree applied based on location data collected during collecting phase. The terrain data that uses Digital Elevation Model (DEM) can be imported into Unity 3D. The terrain engine inside the Unity 3D can be loaded in the terrain structure. This terrain later could be overlaid with satellite imagery data after the terrain have been set up, the placed of the tree could be based on the original location inside the Unity $3 \mathrm{D}$ to simulate actual data coordinate of the oil palm tree location. The manipulation of data will 
occur here, whereby the information of the current tree status and terrains could be visualized.

\subsubsection{Using 3D Modeler Software}

The next section will show modeling of palm tree and what it will look inside Unity 3D environment. The tree is created using 3D Studio Max software. The modeling is based on the real image of the oil palm tree using 3Ds max software. Figure 3 show the process of modeling the palm oil tree, the processes of modeling are separated into three parts: modelling the stem, modeling the fruits, and modeling the leaf. After the modeling is performed, the stem and fruits are textured.

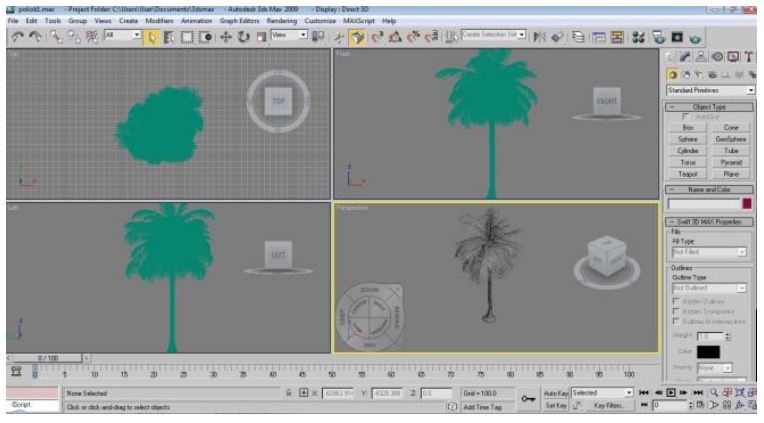

Figure 3 Sample of figure caption image of oil palm tree

\subsubsection{Inside Unity 3D Game Engine}

This section explains how the tree will be imported and displayed in Unity 3D, the 3D file that contains the model of the palm tree is exported in Unity 3D file. And Unity 3D will read the file. However, the texture that is used in creating the model must also be in Unity 3D to allow Unity $3 D$ to read the texture file from the $3 D$ modeller, Figure 4 show the sample image on the construction of terrain and oil palm tree inside Unity 3D. While, Figure 5 and Figure 6 shows different views of oil palm tree at different angles which can be achieved using Unity 3D to show vital information.

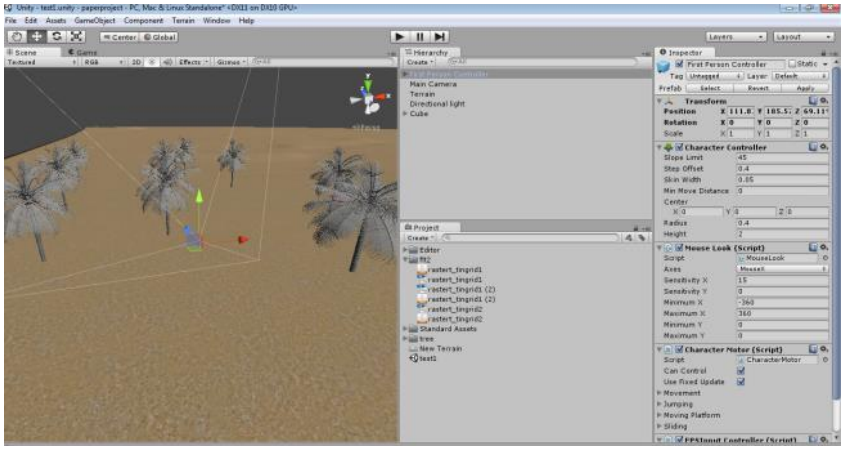

Figure 4 Sample of construction of terrain and tree inside Unity 3D

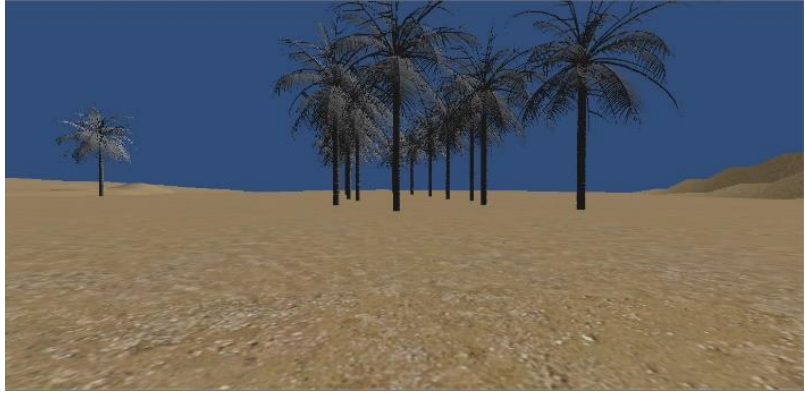

Figure 5 Sample of long shot view of the terrain with oil palm tree when it being published

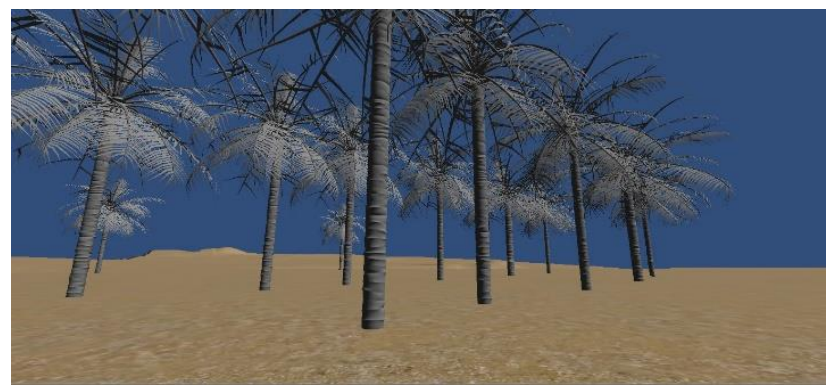

Figure 6 Sample of close up view of the terrain with oil palm tree when it being published

\subsection{Deployment phase}

The final phase is the deployment phase, during this phase everything could be prepared for online deployment; the application can be setup as to enable online access. The information such as the server, client and database, is ready to be deployed.

As the expected results from this conceptual idea of developing of online 3D oil palm management system based on game engine technology, the proposed system development at final stage could be deployed into the web server. From this point, the users especially the manager of oil palm plantation can make use of this applications for managing their oil palm plantation effectively. The advantages of this type of applications are that because of online availability, the system can be accessed anytime, anywhere and at any place.

\subsection{CONCLUSION}

The conceptual idea of developing online 3D oil palm management system based on game engine technology has met in successful. The methodology on how to make the system in reality has been proposed. Unity 3D game engine is been proposed to be utilized for developing the system. The idea on developing the system by using Unity 3D has been discussed and the expected results being explain. By utilizing the game engine capability to create this kind of system, the information gather from actual oil palm plantation 
data such as terrain information, tree location and status, satellite images, and management practice data could be used. As the real terrain data could be used for real world simulation in the future system, it is vital for decision makers to understand what information that they can gather for decision making process. Game engines allow so much customization as able to construct an online 3D oil palm plantation, this idea would be beneficial to everyone especially future developers who might expand this idea.

\section{Acknowledgment}

The authors would like to express their sincere appreciation to Universiti Utara Malaysia for funding this project under "Penyelidikan Berkumpulan Impak Tinggi (PBIT)". Without their support and helps, this project could not be a success.

\section{References}

[1] Kaufman, A. E. 1996. Volume Visualization. ACM Comput. Surv. 28(1): 165-167.

[2] Hanif, A. 2009. Ladang Digital Kelapa Sawit. Harian Metro. ed, 2009.

[3] Adaem. 2011. Ladang Digital. [Online]. From: http://sawitbiz.com/ladang-digital/ [Accessed on 11 September 2011].

[4] Navarro, A., Pradilla, J. V. and Rios, O. 2012. Open Source 3D Game Engines for Serious Games Modeling. Modeling and Simulation in Engineering. 143-158.

[5] Yang, T. 2004. Game Engine Support for Terrain Rendering in Architectural Design. Computer Science-University of Auckland, 2004.

[6] Lewis, M. and Jacobson, J. 2002. Introduction. Commun. ACM. 45(1): 27-31.

[7] Nilson, B. and Söderberg, M. 2007. Game Engine Architecture. Mälardalen University 2007.

[8] Tory, M., Moller, T., Atkins, M. S., and Kirkpatrick, A. E. 2004. Combining $2 \mathrm{D}$ and $3 \mathrm{D}$ views For Orientation And Relative Position Tasks. Presented at the Proceedings of the SIGCHI Conference on Human Factors in Computing Systems, Vienna, Austria, 2004.

[9] Cho, P., Anderson, H., Hatch, R. and Ramaswami, P. 2006. Real-Time 3D Ladar Imaging. 35th IEEE Applied Imagery and Pattern Recognition Workshop. Washington, DC. 11-13 Oct. 2006. 5.

[10] Emma-Ogbangwo, C., Cope, N., Behringer, R. and Fabri, M. 2014. Enhancing User Immersion and Virtual Presence in Interactive Multiuser Virtual Environments through the Development and Integration of a Gesture-Centric Natural User Interface Developed from Existing Virtual Reality
Technologies. In $\mathrm{HCl}$ International 2014 - Posters' Extended Abstracts. vol. 434, C. Stephanidis, Ed., ed: Springer International Publishing. 410-414.

[11] Linden Research Inc. 2014. Second Life Official Site - Virtual Worlds, Avatars, Free 3D Chat. [Online]. From: http://secondlife.com/ [Accessed on 4 August 2014].

[12] Oculus, V. R. 2014. Next Gen Virtual Reality. [Online]. From: http://www.oculusvr.com/rift/ [Accessed on 4 August 2014].

[13] VRvana. 2014. VRvana - Virtual Reality for everyone. [Online]. From: http://www.vrvana.com/ [Accessed on 4 August 2014].

[14] GameFaceLabs.com. 2014. Game Face Preview. [Online]. From: http://gamefacelabs.com/\#!home [Accessed on 4 August 2014].

[15] Michaelenger. 2014. Game Engines: How do they work? [Online]. From: http://www.giantbomb.com/profile/michaelenger/blog/game-engines-how-do-they-work/101529/ [Accessed on 4 August 2014].

[16] Naughtydog.com. 2014. Naughty Dog Game Engine. [Online]. From: http://www.naughtydog.com/ [Accessed on 4 August 2014].

[17] Crytek. 2014. CryEngine. [Online]. From: http://cryengine.com/ [Accessed on 4 August 2014].

[18] HB Studios. 2014. The Golf Club - a video game by HB Studios. [Online]. From: http://thegolfclubgame.com/ [Accessed on 4 August 2014].

[19] Greenyer, F. 2013. A Military Game Engine Primer. MS\&T: Military Simulation \& Training. Available: http://halldale.com/insidesnt/military-game-engineprimer\#.U-bTOmOZgsw.

[20] Ruzinoor, C. M., Abdul Rashid, M. S., Abdul Nasir, Z., Mohd Shafry, M. R. and Mohd Hafiz, M. 2014. Using Game Engine For 3D Terrain Visualisation Of GIS Data: A Review. IOP Conference Series: Earth and Environmental Science. 20(2014)

[21] Sa, W., Zhengli, M., Changhai, Z., Huili, G., Shanshan, L. and Beibei, C. 2010. A New Method Of Virtual Reality Based on Unity 3D. 18th International Conference on Geoinformatics. 18-20 June 2010. 1-5.

[22] Tan, K., Lee, K., Mohamed, A. and Bhatia, S. 2009. Palm Oil: Addressing Issues And Towards Sustainable Development. Renewable and Sustainable Energy Reviews. 13(2): 420-427.

[23] Bergert, D. L. 2000. Management Strategies Of Elaeis Guineenis (Oil Palm) In Response To Localized Markets in South Eastern Ghana, West Africa. Michigan Technolocical University.

[24] Donough, C., Witt, C. and Fairhurst, T. 2009. Yield Intensification In Oil Palm Plantations Through Best Management Practice. Better Crops. 93(1): 12-14.

[25] Sharma, M. 2013. Sustainability in the Cultivation of Oil PalmIssues \& Prospects for the Industry. Journal of Oil Palm, Environment and Health (JOPEH). 4.

[26] Griffiths, W. and Fairhurst, T. 2003. Implementation Of Best Management Practices In An Oil Palm Rehabilitation Project. Better Crops International. 17(1): 16. 